\title{
SEBUAH TINJAUAN MENGENAI STIMULUS BERPIKIR KRITIS BAGI SISWA SEKOLAH DASAR
}

\author{
Romirio Torang Purba \\ romirio_tpoerba@yahoo.com \\ Program Studi Pendidikan Guru Sekolah Dasar - FKIP UKSW Salatiga
}

\begin{abstract}
ABSTRAK
Berpikir kritis adalah proses berpikir yang cukup kompleks. Kekompleksannya ini membuat sebagian orang pesimis untuk bisa menghadirkannya dalam proses pembelajaran di sekolah dasar. Temuan dari hasil-hasil penelitian beraneka ragam, namun tetap, masih menjadi pertanyaan, stimulus apa yang paling memungkinkan bagi siswa sekolah dasar untuk berpikir kritis. Tulisan ini bertujuan untuk menjelaskan hal mendasar yang dapat menstimulus berpikir kritis di sekolah dasar. Melalui pembahasan dari beberapa literatur, ditemukan bahwa masalah dan dialog dapat menjadi dasar bagi kehadiran berpikir kritis dalam proses pembelajaran di sekolah dasar.
\end{abstract}

Kata kunci: berpikir kritis, masalah, dialog

\section{PENDAHULUAN}

Berpikir itu sendiri, pada dasarnya sebuah konsep yang biasa didengar sehari-hari. Aktivitas berpikir adalah aktivitas yang mendasar dilakukan manusia. Berpikir membedakan manusia dengan makhluk hidup lainnya. Manusia melakukan kegiatan berpikir, tapi hewan tidak. Berpikir sepertinya hakikat manusia. Bochenski (dalam Suriasumantri, 2012) menyatakan defenisi yang cukup sederhana mengenai berpikir. Berpikir berarti aktivitas otak dalam mengembangkan ide dan konsep. Ketika seseorang diminta untuk memikirkan keluarganya, maka ia akan berpikir mengenai siapa saja anggota-anggota yang ada di keluarganya, apa pekerjaan masing-masing anggota keluarga, siapa yang paling ramah di keluarga, dan hal lain yang menyangkut tentang keluarga. Aktivitas ini menunjukkan sebuah pengembangan dari sebuah ide atau konsep yang diberikan. Itulah berpikir.

Pada umumnya, karena berpikir adalah aktivitas yang dilakukan semua manusia, maka hal itu tidak sukar untuk dilaksanakan. Manusia sudah pada dasarnya berpikir. Dan pada makna itu, benar bahwa berpikir itu mudah. Cuma memikirkan jam berapa kuliah akan selesai, kapan harus pergi ke kampus, mau beli apa untuk hidangan makan malam, dan lain sebagainya, semua orang bisa. Tapi untuk berpikir kritis, tidak mudah. Tidak semua orang mudah melakukannya. Berpikir kritis adalah berpikir tingkat tinggi. Aktivitas mental yang dianggap penting untuk dibahas dari tahun ke tahun. Pentingnya kemampuan ini dapat dilihat kehadirannya di berbagai sistem pendidikan atau kurikulum di dunia (Massa, 2013), 
Sebuah Tinjauan Mengenai Stimulus Berpikir Kritis bagi Siswa Sekolah Dasar (Romirio Torang Purba)

sehingga yang diungkapkan Halpern (2003) tepat, bahwa berpikir kritis itu sendiri adalah tujuan pendidikan.

Tulisan ini, membahas hal mendasar yang dapat menstimulus kehadiran berpikir kritis siswa di sekolah dasar. Dari pembahasan dari beberapa literatur mengenai berpikir kritis, kemudian ditarik simpulan sebagai hal mendasar yang perlu dilaksanakan di sekolah dasar untuk berpikir kritis.

\section{PENGERTIAN BERPIKIR KRITIS}

Berpikir kritis adalah aktivitas mental yang cukup kompleks. Ketika berpikir kritis, seseorang harus mampu memberikan sebuah alasan, merefleksikan sebuah pengalaman, serta dapat membuat keputusan secara mandiri (Brookhart, 2010), Itu artinya, jika ada sebuah alasan yang timbul dari refleksi akan pengalaman tertentu yang mengarahkannya dalam mengambil sebuah keputusan tertentu, maka itulah yang disebut berpikir kritis.

Dalam aktivitas berpikir kritis, Lau (2011) menyebutnya sebagai sebuah kedisplinan untuk merefleksikan alasan-alasan di balik suatu tindakan. Disiplin berarti membiasakan diri, konsisten untuk melakukannya. Tindakan-tindakan, apapun jenisnya, dicari tahu penyebabnya muncul tindakan-tindakan tersebut, dan itu dibiasakan.

Ada sebagian yang menganggap bahwa berpikir kritis cukup dengan banyak bertanya. Hal ini keliru. Mason (2008) berpendapat berpikir kritis membutuhkan kehadiran sebuah pertanyaan-pertanyaan yang menyelidik, yang sifatnya untuk mencari tahu substansial dari suatu pesan untuk menilai hal tersebut benar atau salah. Jadi, tidak cukup hanya banyak bertanya.

Berpikir kritis juga bukan berarti banyak menjawab pertanyaan-pertanyaan. Berpikir kritis justru harus mempertanyakan jawaban-jawaban, fakta-fakta, atau segala informasi yang ada untuk menarik sebuah kesimpulan (Noer, 2009). Itu pun tidak terburu-buru, untuk menetapkannya sebagai sebuah kesimpulan.

Ennis (1993) menyatakan bahwa berpikir kritis memerlukan waktu untuk berefleksi. Itu berarti, waktu yang dibutuhkan untuk melakukannya, tidak sebentar. Seseorang harus menguraikan segala sesuatunya hingga masuk akal dengan waktu yang cukup lama. Dan dari situ, kemudian ditentukan apa yang harus dipercayai, apa yang tidak, dan apa yang harus dilakukan, apa yang tidak.

\section{HAMBATAN BERPIKIR KRITIS}

Sebuah pengalaman pada tanggal 3 Desember 2013, di salah satu sekolah dasar negeri favorit di Jawa Timur, didapati bahwa buku ajar IPA (LKS) yang dipakai tidak mengindikasikan materi yang membiasakan siswa untuk berpikir kritis. Soal-soal yang ada pada LKS (Lembar Kerja Siswa) hanya mendorong siswa untuk menjawab hal-hal yang bersifat hafalan. Pranoto (Kompas, 2013) 
mengemukakan bahwa sekolah Indonesia itu memang terlalu fokus mengajarkan kecakapan yang sudah kadaluwarsa, seperti menghafal dan berhitung ruwet, sedangkan untuk kemampuan berpikir kritis itu sendiri, jarang diajarkan kepada siswa.

Kemungkinan ini dapat menjadi dasar yang membuktikan bahwa faktor lingkungan bisa berperan besar meniadakan aktivitas berpikir kritis. Oleh karena itu, berpikir kritis ternyata memerlukan sebuah lingkungan yang mendukung untuk menghadirkannya. Berpikir kritis memerlukan stimulus. Selain itu, ternyata tidak lingkungan saja. Berpikir kritis juga ternyata, secara mekanis, tidak disukai oleh otak manusia.

Willingham (2009) menyatakan bahwa otak siswa ternyata cenderung menghindari kegiatan berpikir. Ia tidak selalu berdampingan baik dengan kerja otak. Pada anak usia sekolah dasar, otak manusia cenderung suka pada kegiatan yang melibatkan penglihatan dan gerakan. Jadi wajar, kegiatan berpikir menjadi kegiatan yang biasanya tidak disukai siswa. Seorang pendidik harus mampu merancang suatu aktivitas pembelajaran yang membuat kegiatan berpikir itu menjadi mudah dan menarik bagi siswa. Kegiatan pembelajaran yang melibatkan penglihatan dan gerakan-gerakan tubuh, artinya yang nyata (konkrit) bagi siswa. Tidak cukup hanya pemberian beberapa metode pembelajaran.

\section{STIMULUS BERPIKIR KRITIS}

Berpikir kritis tidak muncul begitu saja. Ia membutuhkan stimulus yang tepat untuk dapat hadir, khususnya di dalam kelas. Tan (2003) menyatakan bahwa pembelajaran yang hebat, dimulai dari masalah. Dalam pandangannya, masalah membuat orang asyik. Keasyikan menghadapi sebuah masalah. Apa yang digambarkan Tan mengenai masalah bukanlah masalah yang biasa digambarkan banyak orang sebagai sebuah sebuah keadaan yang menyusahkan pada saat itu juga.

Masalah yang dimaksud adalah segala keadaan yang menimbulkan pertanyaan dalam diri siswa yang kemudian menjadi obyek pembahasan dalam pembelajaran. Dalam hal ini, maka guru dan siswa sama-sama mengarahkan fokus pertemuan mereka untuk membahas masalah tersebut. Siswa tidak dipandang sebagai obyek dan guru sebagai subyek. Siswa dan guru menjadi rekan. Kondisi menstimulus stimulus siswa untuk berpikir. Ia mengambil masalah tersebut menjadi hak miliknya dan kemudian melibatkan banyak dimensi berpikirnya.

Duch dkk., (2001) memang menganggap masalah sebagai hal yang membuat siswa "belajar bagaimana belajar", bekerja secara kelompok untuk mencari solusi dari permasalahan dunia nyata. Itu artinya, secara natural, jika seseorang mendapat sebuah masalah, maka ia akan mengaktifkan pikirannya. Ia juga akan terdorong menukarkan pikiran dengan orang-orang di sekitarnya. Bisa 
Sebuah Tinjauan Mengenai Stimulus Berpikir Kritis bagi Siswa Sekolah Dasar (Romirio Torang Purba)

saja memang, ketika ia memikirkannya sendiri, berpikir kritis tetap terjadi. Tetapi tetap saja, kehadiran masalahlah yang merangsang dia untuk merefleksikan banyak hal. Masalah yang didesain oleh guru yang mengajarnya.

Glazer (2001) menyebut masalah sebagai pengaktif belajar siswa. Sebagaimana yang dikatakan Trianto (2007) bahwa masalah itu memampukan siswa untuk menyusun pengetahuannya sendiri, menumbuhkembangkan kemampuan berpikir tingkat tinggi dan inkuiri, memandirikan siswa, serta meningkatkan kepercayaan dirinya.

Selain masalah, ada jalan lain untuk menstimulus berpikir kritis siswa. Hal itu adalah dialog. Kesempatan individu untuk berdialog dengan invidu lainnya akan menajamkan apa yang dipikirkan masing-masing individu tersebut. Dubin (2001) menyatakan bahwa otak manusia aktif ketika pemikiran dituangkan menjadi sebuah kalimat yang terucapkan. Gregory (1886) menyebutnya (bahasa) sebagai pengantar buah pikiran. Jadi, berdialog memungkinkan berpikir kritis terjadi.

Ketika siswa mengungkapkan segala hal yang dipikirkannya ke dalam bahasa atau kalimat-kalimat, maka ada yang membalas. Keadaan ini membuat konflik kognitif. Mereka berbicara pada suatu saat, namun pada kesempatan lain melakukan kegiatan menyimak hal-hal yang diucapkan rekan mereka lainnya.

Relasi ini menimbulkan rangsangan bagi siswa untuk mengungkapkan halhal yang telah diketahuinya serta memberikan pertanyaan ketika suatu hal belum jelas untuk dimengertinya. Ini membuat otak siswa berkembang. Pikiran siswa diberdayakan melalui dialog.

Slavin (1996) menyebut ini sebagai manfaat dari pengalaman berkomunikasi. Pengalaman berkomunikasi dengan teman sebaya, menolong siswa menguasai proses kognitif mereka, seperti kemampuan membuktikan dan kemampuan mengkritisi. Sama juga seperti yang dikatakan Vygotsky (1986). Ia menyatakan bahwa setiap individu akan mengkonstruk pengetahuannya dalam struktur serta interaksi sosial kehidupannya.

\section{SIMPULAN}

Berpikir kritis adalah proses berpikir yang penting diimplementasikan di sekolah dasar. Sekalipun tidak mudah untuk mengimplementasikannya. Namun bukan berarti, berpikir kritis tidak dapat dihadirkan dalam sebuah pembelajaran di sekolah dasar.

Hal yang pertama dapat dilakukan adalah penghadiran masalah. Masalah dihadirkan untuk membuat siswa bertanya. Dalam pembelajaran yang menggunakan masalah, bukan guru yang bertanya, siswa yang bertanya. Dengan demikian, pertanyaan yang timbul adalah karena stimulus masalah. Peran guru dalam pembelajaran yang menggunakan maasalah adalah sebagai pendamping. Tapi bukan berarti, ketika masalah diberikan, siswa terus dibiarkan begitu saja. Guru sejelas 
mungkin merancang masalah bagi siswa yang membuat ia memunculkan pertanyaannya sendiri dan membuat dia berinisiatif (mandiri) untuk menjawabnya sendiri.

Hal kedua yang dapat dilakukan untuk menstimulus siswa berpikir kritis adalah dialog. Dialog adalah sebuah proses yang memberi kesempatan kepada siswa untuk menyampaikan pikirannya kepada orang lain dan merefleksikan pikiran orang lain yang diterima dirinya. Keadaan ini membuat siswa tidak menyimpan sendiri pikirannya. Proses ini membuat apa yang dipikirkannya semakin tajam. Dialog perlu didesain. Salah satunya, bisa dengan sebuah pertentangan yang mengakibatkan konflik kognitif.

\section{DAFTAR RUJUKAN}

Brookhart, S. M. 2010. How to Asses High - Order Thinking Skills in Your Classroom. Virginia: ASCD.

Dubin, M. Wm. 2001. How the Brain Works. Massachusetts: Blackwell Science.

Duch, B. J., Groh, S. E. \& Allen, D. E. 2001. The Power of Problem-Based Learning: a Practical "How To" for Teaching Undergraduate Courses in Any Discipline. Virginia: Stylus Publishing.

Ennis, R. H. 1993. Critical Thinking Assesment. Theory Into Practice, 32 (3): 179186.

Glazer, E. 2001. Using Internet Primary Sources to Teach Critical Thinking Skills in Mathematics. London: Greenwood Press.

Gregory, J. M. 1886. The Seven Laws of Teaching. Boston: Congregational Sunday School and Publishing Society.

Halpern, D. F. 2003. Though \& Knowledge: An Introduction to Critical Thinking ( $4^{\text {th }}$ Ed.).New Jersey: Lawrence Erlbaum Associates, Inc.

Lau, J. Y. F. 2011. An Introduction to Critical Thinking and Creativity: Think More, Think Better. New Jersey: John Wiley \& Sons, Inc.

Massa, S. 2014. The Development of Critical Thinking in Primary School: The Role of Teachers' Beliefs. Procedia-Social and Behavioral Science, 141: 387392.

Noer, S. H. 2009. Peningkatan Kemampuan Berpikir Kritis Matematis Siswa SMP melalui Pembelajaran Berbasis Masalah. Makalah disajikan dalam Seminar Nasional Matematika dan Pendidikan Matematika, Jurusan Pendidikan Matematika FMIPA UNY, Yogyakarta, 5 Desember 2009.

Slavin, R. E. 1996. Research for The Future: Research on Cooperative Learning and Achievment: What we know, What We need to Know. Contemporary Educational Psychology, 21(4): 43-69. 
Sebuah Tinjauan Mengenai Stimulus Berpikir Kritis bagi Siswa Sekolah Dasar (Romirio Torang

Purba)

Suriasumantri. 2012. Ilmu dalam Perspektif. Jakarta: Yayasan Pustaka Oboer Indonesia.

Tan, O. S. 2003. Problem-Based Learning Innovation: Using Problems to Power Learning in the 21st Century. Shenton Way: Wadsworth Cengage Learning.

Trianto. 2007. Model- Model Pembelajaran Inovatif Konstruktif. Jakarta: Prestasi Pustaka.

Vygotsky, L. S. 1986. Thought and Language (Alex Kozulin, Ed.). London: The MIT Press.

Willingham, D. T. 2009. Why Don't Students Like School?: a Cognitive Scientist Answers Question about How The Mind Works and What It Means for The Classroom. San Fransisco: Jossey-Bass. 